\title{
Bank Scale of Economies, Banking Industry Concentration, and Competition Level: The Indonesian Case
}

\author{
BUDDI WIBOWO
}

\begin{abstract}
Graduate School of Management Faculty of Economics and Business Universitas Indonesia, Depok 16424, Indonesia
\end{abstract} Email correspondence: buddi.wibowo74@gmail.com

\begin{abstract}
Banking sector efficiency in a country is directly influenced by regulations that set up by the banking authorities in that country, especially what kind of banking industry structure that regulator intend by those regulation. Indonesian Banking Architecture which encourage mergers and acquisitions of smaller banks, has a clear target that Indonesian banking industry should have a leaner industry structure with fewer number of banks but with relatively large assets, higher industry concentration higher and more tighter competition. This policy is driven by the regulator's belief that Indonesian banks has not achieved its economies of scales and competition is relatively low so that the Indonesian banking operating costs are among the highest among Asian countries. The opposite actually happened in the USA where the regulator is precisely to prevent mergers between major banks due to economies of scale bank in the United States has been exceeded. The reserach results showed the group of large banks in Indonesia is more efficient than medium and small banks and the efficiency is more due to economies of scale than caused by the concentration of the industry and the level of competition between banks.
\end{abstract}

Key words: Economies of scale, industry concentration, banking competition

\section{Skala Bank Ekonomi, Konsentrasi Industry Perbankan, dan Level Persaingan: Kasus Indonesia}

\begin{abstract}
Abstrak
Efisiensi sektor perbankan sebuah negara sangat dipengaruhi regulasi otoritas perbankan di negara tersebut berkaitan dengan struktur industri perbankan yang ingin dibentuk oleh regulator. Arsitektur Perbankan Indonesia misalnya mendorong proses merger dan akuisisi bank-bank kecil dengan tujuan akan tercapai struktur industri yang lebih ramping dengan jumlah bank lebih sedikit namun dengan asset yang relatif besar, konsentrasi industri perbankan yang lebih tinggi serta kompetisi yang lebih ketat. Kebijakan ini didorong oleh keyakinan regulator bahwa skala ekonomis operasional perbankan di Indonesia selama ini belum tercapai dan kompetisi yang relatif rendah sehingga biaya operasional perbankan Indonesia termasuk yang tertinggi di antara negara Asia. Sebaliknya justru terjadi di Amerika Serikat dimana regulator justru mencegah merger antara bank-bank besar karena skala ekonomis bank di Amerika Serikat telah terlampaui. Hasil uji menunjukkan kelompok bank besar di Indonesia lebih efisien dibandingkan bank menengah dan kecil dan efisiensi tersebut lebih disebabkan skala ekonomis bank besar lebih baik daripada disebabkan oleh konsentrasi industri dan tingkat persaingan antar bank.
\end{abstract}

Kata kunci: Skala Ekonomis, Konsentrasi Industri, Kompetisi Perbankan 
JURNAL BISNIS \& MANAJEMEN

ISSN 1412 - 3681

\section{INTRODUCTION}

\section{Background}

Banking Industry is one of industry which usually have high concentration that majority of industry asset owned by few big banks. In order to increase efficiency and market share this big banks tend to acquire another banks or other financial institution that cause concentration level of banking industry become more higher and form a financial conglomerate. Indonesia Banking Architecture, launched by Indonesia Financial Service Authority explicitly urges small banks to have consolidation plan to state a merger between them, invite foreign bank to buy their share and store more capital. Concentration level of banking industry will be higher in the future.

This conceptual framework emerge from EfficientStructure paradigm (Demsetz, 1973) that state efficient bank will be a winner in banks competition, acumulate profit and capital, and expand its market share so that banking industry will become more concentrated. Bank efficiency is affected by bank's asset size. Big bank can achieve economies of scale and has a natural competitive cost compared to its competitors (Hughes and Mester (2013) and Kovner, Vickrey and Zhou (2014)). Beccalli, Anolli, and Borello (2015) show that big banks in European countries operates as a big financial conglomerate with broad financial services and far more efficient than their smaller competitors. Feng and Serlitis (2010) found same result in USA banks. Their studies show that USA big banks had achieved their economies of scales and were able to minimize cost. Feng and Zhang (2014) and Bossone and Lee (2004) show banks'economies of scale that reflected on banks' profitability, were not only affected by bank asset size but also by corporate culture, bank risk profile and banking industry concentration.

Other studies, e.g Wheelock and Wilson (2012) and Berger et al (1993) show different result. Smal banks and big banks were on extreme U-shaped average cost. Small banks were not able to achieve their economies of scale so they have relatively higher cost. On the other hand, big banks were not efficient also because their asset were far above economies of scales. Only medium size- banks that operated in their economies of scales. Berger et al (1993) show that USA bank economies of scales were around US\$300 million that were at 6 th percentile or around $60 \%$ bank asset distribution in 1990. Clark [1996] has similar result that bank average cost curve was $U$ shaped that relatively flat in the middle curve so small and big banks have diseconomies of scale. Big banks were not operationally efficient because of very wide chain of command and geographicaly very dispersed bank branch locations. Big banks also tend to take higher risk because its managers believe government always help them when these systemic banks have serious problems.

De Young et al (2011) show that big bank cost function is different from smaller banks because they serve different market segments and different type of banking services. More bigger bank size, documented by Wheelock and Wilson (2012) and Demirguc-Kunt and Huizinga (2010), they less depend on expensive traditional time deposit, were more active raising capital through capital market instrument. Cost function difference between large bank and small one implied that every bank can achieve their specific economies of scale. Banking economic scales can be reached not only by large banks but also by medium and even by small ones.

Bank efficiency affected by level of competition in banking industry (Wheelock dan Wilson (2012); Wibowo (2015). If each group of bank size serve different segment of consumers then competition level in those group will be different. The level of competition differences is proved that it influences operational efficiency level for any bank groups. Feng dan Serlitis (2010) found that competition have different impact on bank operational efficiency.

This review show that there are some conceptual framework that have very different explanation on bank's scale of economies. On the other hand, there are many bank mergers and acquisitions that occur because of favorable regulations for big bank existency. Few big banks that play dominant role in baking industry have high systemic risk impact and have serious implication, not only on the banking sector but also on the economy.

Few but dominant big bank. Domination of large banks and high industrial competition anxiously 
instigate low competition leading to oligopoly causing inefficiency. This is where the emerging contradiction amid banking efficiency, the concentration of the banking industry, competition among banks and financial system stability. Research in empirically test the relationship of all these concepts in the context of Indonesian banks is interesting and necessary, not only from the point of academic interest but more importantly as the basis for a reconsideration of the policy in the Indonesian banking industry over the years.

Empirical testing in the context of the Indonesian banking became exciting because Indonesian banks have special characteristics that profitability is high enough, the market of banking services are segmented by the lots of banks, the distribution of assets is quite extensive between large banks and small ones, banking credit penetration is still relatively low and capital markets are underdeveloped.

\section{Research Problem}

The economic-scale measurement of banks should be based on the accounts of banks to be able to accommodate the alleged variances in the cost function among groups of banks. Differences in bank fees function can be identified from the variances between the cost structure of small banks, mediumsized and large ones. This study empirically examine the banking cost structure of three groups of banks.

To understand the cost structure differences of the group size of the bank, some of the determinants regarding bank operational efficiency and their impacts needs to be tested. As found by Wheelock and Wilson (2012) the difference in the cost structure of the US banking is determined in part by the level of competition. Wibowo (2015) found no significant relationship between the Indonesian banking efficiency with the level of competition between banks. Wibowo (2015) finding is suspected due to competition and efficiency measurements carried out on the entire banks, it did not consider the variances in the function of cost, efficiency, and competitions amongst groups of banks as found by Wheelock and Wilson (2012). This study will measure competition and efficiency for the three groups of banks by size of assets in Indonesia which are large banks, small and medium-sized ones.
Industry concentration is frequently used to measure the level of competition within an industry. The problem is the method of measuring the degree of it is debatable on its accuracy. The empirical banking research shows the concentration does not fully reflect accurately the level of banking industry competition (Bikker, Shaffer and Spierdijk (2012); Maudos and Solis (2011)). The high industry concentration, does not necessarily mean a low level of competition, while the low concentration is not necessarily a very tight competition. This measurement problem encourages researchers to develop a more reliable banking competition measurement (Bikker, Shaffer and Spierdijk (2012); Berger, et al 2004).

Industrial organization approach in assessing the competition is divided into two groups: structural and non structural approaches (Bikker, 2004). Because the industrial structure measurement empirically and structurally has intractable problem, banking research prefers to use non-structural models (reducedform model) to measure banking competition. The models exhibit the behavior of the competition with the conceptual framework of the New Empirical Industrial Organization (NEIO). This model measures the degree of industry competition by analyzing the behavior of competing (competitive conduct) of firms in an industry without using explicit information concerning the structure of the industry. Such models are Panzar and Rosse model (1987). It measures competition by estimating the amount of deviation between the existing conditions with competitive pricing decision that occurs in an industry.

Panzar and Rosse (1987) construct an empirical test that can distinguish the type of competition of an industry into three types, namely the oligopolistic market competition, monopolistic and perfect competition. It is a model of banking competition which quite widely used in banking research (Bikker, Shaffer and Spierdijk (2012). This study will use PanzarRosse model to measure the level of competition.

\section{LITERATURE REVIEW}

In recent decades, the bank is growing very rapidly in terms of the value of its assets. Some banks become very large absolutely and relatively to the banking industry in their respective countries, even 


\section{JURNAL BISNIS \& MANAJEMEN}

ISSN 1412 - 3681

comparatively to the country's economy as a whole. Between 2006 and 2014, the value of assets owned by the four largest commercial bank in the United States increased from $39 \%$ to $44 \%$ of the total banking assets. The economic crisis in Europe and the United States show the systemic effects of a large bank may lead to serious repercussions. The failure of a bank in Ireland in 2010 encouraged the Irish government requesting financial aid from the EU and IMF. After the bank bail-out is facilitated by the EU, the Irish found the need to reduce the large banks in the country adjusted to the amount of its economy. In the UK, the Bank of England has raised public debate to gain public approval of the plan of split up of major banks in the UK in order to suppress the financial risk faced by the government.

In the US, Wall Street Reform and Consumer Protection Act, also known as the Dodd-Frank Act passed in July 2010 which forbade the merger between banks that can create a bank that has total liabilities exceeding 10 percent of all liabilities within the financial companies cummulatively in order to prevent the emergence of a bank that is too large.

The existence of regulatory limitations to the bank in increasing its assets raises the attention of researchers on achieving economies scale of the banks. The determination of the asset scale that a bank can operate most efficiently becomes an important question preceding a debate between researchers and policy makers and the banking authority. Hughes and Mester (2013), Wheelock and Wilson (2009) and Feng and Serletis (2010) found evidence that large banks are more productive and more efficient than small ones. Their findings are in contrast to previous research findings by Berger et al (1993).

They found the differences in their research because technological development bank in the 2000s is much more sophisticated than the 1990s as observed by Berger et al (1993). Becalli et al. (2015) also found the same thing in Europe, a large European bank operating under conditions of increasing returns to scale. Kovner et al. (2014) showed large banks have an average operating cost much lower than smaller ones. But the findings Feng and Zhang (2014) shows the economic scale of the bank with enormous assets worth at least US $\$ 1$ billion and most banks in America
Jurnal Bisnis \& Manajemen, 2016, Vol. XVII, No. 1, 58-72

have constant returns to scale. And Kumbhakar-Tobon Restrepo (2015) found only 35\% of the largest banks in the US banking has increasing returns to scale.

The difference in efficiency of banking operations is attributed to the achievement of the economic scale in terms of assets, triggered also by the level of competition and the structure of the banking industry. Kumbhakar-Tobon and Restrepo (2015) found the major banks achieve increasing returns to scale precisely because of the competition intensity among the major banks.

The notion that large banks enjoy benefits as ones with assets or termed as a "quiet life", according to Tobon Restrepo and Kumbhakar (2015) is not proven. Precisely the fierce competition in the group of large banks that make them put out extra effort to be always more efficient than its competitors. The efficient large banks look for less efficient ones for targeted acquisitions and converted into a more resourceful bank. Market dominance of the major banks will be more influential.

\section{The Indonesian Banking}

Competition among banks in Indonesia can be categorized as non-price competition. This can be indicated by Suku Bunga Dasar Credit (SBDK), the prime lending rate, applied by Indonesian banks that have fairly wide dispersion range among banks. The standard deviation of the rate in Indonesia was recorded nearly $2.09 \%$. (Table 1 ). For comparison, the standard deviation in Malaysia and Thailand is only about $0.3 \%$ (Table 2). The much higher bank lending can continue to exist because it offers another feature that is valuable in the eyes of its customers.

The average and standard deviation of the prime lending rate that banks serve SME customers tend to be much higher than corporate loans and retail. Market segmentation of banking services in the SME segment seems stricter limits segment. Standard deviation for SME prime lending rate to reach $4.5 \%$. This ranges may be an indication of a segmented banking market thus enabling banks to behave as a monopolist in each segment and determine varied and competitive lending rates through factors other than price (interest rate). 
Jurnal Bisnis \& Manajemen, 2016, Vol. XVII, No. 1, 58-72

Table 1 The Indonesian Banking Prime Lending Rate (SBDK)

\begin{tabular}{cccc}
\hline & \multicolumn{3}{c}{ Prime Lending rate (\%) } \\
\cline { 2 - 4 } & Corporate Loan & Retail Loan & Micro Loan \\
\hline Average & 10.70 & 11.65 & 14.04 \\
Median & 10.75 & 11.65 & 13.43 \\
Standard of Deviation & 2.09 & 1.92 & 4.53 \\
\hline
\end{tabular}

Source: Otoritas Jasa Keuangan

Table 2 The Prime Lending Rate in Malaysia, Thailand and The Philipines

\begin{tabular}{cccc}
\hline & \multicolumn{3}{c}{ Prime Lending Rate (\%) } \\
\cline { 2 - 4 } & Malaysia & Thailand & Philippines \\
\hline Average & 3.99 & 6.75 & 5.35 \\
Median & 3.95 & 6.55 & 5.05 \\
Standard of Deviation & 0.35 & 0.57 & 0.75 \\
\hline
\end{tabular}

Sources: Bank Negara Malaysia, Bank of Thailand, and Bank Sentral of Philippines

Indonesian banking confronts low financial inclusion indicated by the number of bank credit to the Gross Domestic Product (GDP) which is way below neighboring countries (Table 3 ). The banks as a source of funding for companies in Indonesia remains dominant because the capital market through stock exchanges and Indonesian corporate bond market is still very small, this instigates that the bank has a very strong market power in the presence of customers (Table 4). Indonesia's stock market capitalization
JURNAL BISNIS \& MANAJEMEN

ISSN 1412 - 3681

in 2011 was only $45 \%$ of the GDP, Malaysia 144\%, Thailand $81 \%$, the Philippines $73 \%$. While the Indonesian market corporate bonds was only 1:41\% higher than the Philippines were only $0.96 \%$, yet much smaller than in Malaysia, which reached $58 \%$ and Thailand $12 \%$ of its GDP respectively.

Table 3 Comparison of the Bank Credit to GDP (\%)

\begin{tabular}{ccccc}
\hline Tahun & Indonesia & Malaysia & Thailand & Philipines \\
\hline 2000 & 17.63 & 122.80 & 116.63 & 35.05 \\
2001 & 17.19 & 127.66 & 101.21 & 33.68 \\
2002 & 17.90 & 119.58 & 97.20 & 30.90 \\
2003 & 19.24 & 115.15 & 97.67 & 28.85 \\
2004 & 21.54 & 108.34 & 97.33 & 26.97 \\
2005 & 22.67 & 101.84 & 97.71 & 25.18 \\
2006 & 22.54 & 100.69 & 93.93 & 23.44 \\
2007 & 22.68 & 96.98 & 89.55 & 22.44 \\
2008 & 23.41 & 93.76 & 93.14 & 25.22 \\
2009 & 23.94 & 107.59 & 95.91 & 28.65 \\
\hline
\end{tabular}

Continue of Table 3 Comparison of the Bank Credit to GDP (\%)

\begin{tabular}{ccccc}
\hline Tahun & Indonesia & Malaysia & Thailand & Philipines \\
\hline 2010 & 23.74 & 105.06 & 92.17 & 27.79 \\
2011 & 25.35 & 106.40 & 101.91 & 29.79 \\
2012 & 26.38 & 107.80 & 102.56 & 30.27 \\
\hline
\end{tabular}

Source: World Bank

Table 4 Comparison of Indonesian Capital Market and Neighboring Countries

\begin{tabular}{|c|c|c|c|c|c|c|c|c|}
\hline & Indonesia & Malaysia & Thailand & Philippines & Indonesia & Malaysia & Thailand & Philippines \\
\hline 2001 & 14.00 & 127.42 & 27.45 & 41.88 & 1.23 & 35.75 & 12.10 & 0.38 \\
\hline 2002 & 14.18 & 121.36 & 33.07 & 49.30 & 1.20 & 35.63 & 12.25 & 0.47 \\
\hline 2003 & 18.38 & 132.84 & 59.26 & 36.34 & 1.73 & 35.83 & 11.22 & 0.42 \\
\hline 2004 & 24.31 & 143.80 & 75.56 & 28.27 & 2.35 & 35.61 & 10.48 & 0.49 \\
\hline 2005 & 25.69 & 132.49 & 69.12 & 33.71 & 2.23 & 47.42 & 10.43 & 0.71 \\
\hline 2006 & 30.68 & 130.22 & 66.70 & 45.75 & 2.03 & 61.32 & 11.13 & 1.00 \\
\hline 2007 & 40.51 & 148.36 & 70.79 & 59.75 & 1.98 & 62.81 & 11.57 & 1.07 \\
\hline 2008 & 30.26 & 116.10 & 58.09 & 47.47 & 1.57 & 56.49 & 11.91 & 0.93 \\
\hline 2009 & 24.86 & 107.06 & 45.27 & 38.16 & 1.50 & 58.89 & 13.31 & 0.93 \\
\hline 2010 & 39.46 & 138.86 & 67.11 & 60.39 & 1.61 & 58.67 & 13.25 & 1.03 \\
\hline 2011 & 45.06 & 144.09 & 81.69 & 73.90 & 1.41 & 58.09 & 12.73 & 0.96 \\
\hline
\end{tabular}


JURNAL BISNIS \& MANAJEMEN

ISSN 1412 - 3681

\section{Research Methodology}

There are three rules of fees that writers use to measure the difference in cost structure between the group of large banks, medium-sized and small ones such as those used by Bikker, Shaffer, and Spierdijk (2012) and Berger et al (2004), namely: Average Funding Rate (AFR) ie interest expense divided by interest Bearing Liabilities, Price of Personel Expenses (PPE) ie labor costs to total assets, and Price of Capital Expenses (PCE) ie overhead costs as measured by the ratio of the cost of depreciation of fixed assets, administrative costs, and other costs to total assets. The three sizes of these costs are measured for each bank within the group of banks and then calculated the average and standard deviation for each group of banks per year.

Industry concentration is measured using Concentration Ratio that is the percentage of revenues, profits or third party funds controlled by a number of large banks. CR3 is the percentage of mastery of the three biggest companies in the industry, and CR5 is the percentage of the five largest companies. The other commonly used measurement of the industry concentration is the HerfindahlHirschman Index (HHI), which calculates the level of concentration based on the distribution of market shares of all companies that exist in an industry. $\mathrm{HHI}$ concentration ratio is more widely used than Concentration Ratio which can result in erroneous conclusions on the level of concentration of the industry because it measures only the market share of the three or the five biggest companies and ignore the distribution of market share among all the existing companies in an industry.

Concentration Ratio is calculated by using the following formula:

$$
C R=\sum_{i=1}^{k} s i
$$

$\mathrm{CR}$ is Concentration Ratio, si is the bank market share of bank $\mathrm{i}, \mathrm{k}$ is the number of banks operated within a period of calculation.

Two Concentration ratio calculated are CR3 and
CR5 that will show the respective market share of the three and the five largest banks in each period. Concentration ratio is calculated in terms of asset value, the value of loans disbursed, and the value of third-party funds (DPK) that exist in each bank. The higher concentration ratio indicates the structure of the industry is concentrated, where large banks are dominant market share and has a great market power. Concentration Ratio can give erroneous conclusions on the level of concentration of the industry because it only measures the market share of the three (CR3) or five (CR5) largest companies in the industry and ignores the distribution of market share distribution of other companies that exist in the industry. Even distribution of the market share of the three or the five biggest companies that would not be captured by a concentration ratio. For example largest companies control $40 \%$ market share, while the two other largest companies controlled respectively $10 \%$ of the shares will have the same concentration ratio CR3 with industry with the market share of three of the largest companies divided evenly $20 \%$. CR3 to both industries will be the same, namely $60 \%$.

To overcome the shortcoming of the concentration ratio, the author will use also the size of the industry concentration Herfindahl-Hirschman Index (HHI). HHI count all of the company's market share.

$H H I=\sum_{i=0}^{N} S_{i}^{2}$

$\mathrm{HHI}$ is the square of the market share of each bank existing in each period. $\mathrm{N}$ is the total number of banks. $\mathrm{HHI}$ index values range between $1 / \mathrm{N}$ to 1 . Industry with the $\mathrm{HHI}$ is equal to $1 / \mathrm{N}$ means the market share of all companies are equal, the $\mathrm{HHI}$ is equal to one means that there is only one company in the industry (monopoly). $\mathrm{HHI}$ index is equal to 0.15 indicates a low level of industry concentration and intra-industry competition is high. HHI between 0:15 to 0:25 indicate moderate concentrations. 0:25 HHI above indicates a high concentration of the industry. These limits are used by the Department of Justice Government of the United States to assess their anti-trust practices (http://www.justice.gov/atr/herfindahl-hirschmanindex). 
To measure the level of competition of the banking sector, the authors use the approach Panzar-Rosse as used by other researchers such as (Anginer et al (2012), Bikker, Shaffer, and Spierdijk (2012); Samad (2008) and Berger et al (2004). Measuring the level of banking competition by Panzar-Rosse approach is basically the modeling of bank revenue function with the bank price of production factors as an independent variable. Panzar-Rosse bank revenue model assumptions is that the bank has three (3) inputs in the production process that is labor, time deposits, and infrastructure. The price of bank production factors, respectively are: Average Funding Rate (AFR), ie the ratio of interest expense over the period of a year to total third party funds, Price of Personel Expenses (PPE), which is the ratio of labor costs to total assets, and Price of Capital Expenditure (PCE), which is the ratio of the cost of physical assets and other expenses to total assets. The level of banking competition by Panzar-Rosse approach, namely $\mathrm{H}$ statistic is the sum of the three regression coefficients of the three production inputs of the bank.

Competition model by Panzar- Rosse (1987) is the industry competition measurement model, so that competition can be quantified and categorized into three types, namely the market with oligopolistic competition, monopolistic competition and perfect competition. This model is based on a premise that the company will implement a different output prices strategy in response to changes in prices of input factors. The average response to changes in input prices over the sales price of production depends on the behavior of all market participants to compete in the industry. In industries with competition as perfect competition, for example, changes in input prices can not be transferred into higher selling prices since all of the selers only act as price takers in this industry. The company's revenues are very influenced by changes in production input prices on such market. The relationship between input prices to corporate earnings is to be very elastic. The opposite case is in monopolistic or oligopolistic markets, rising input prices can be transmitted to the selling price of production output because the company has substantial market power as a monopolist. Corporate profits become relatively more stable although input prices moved up drastically.
In order to derive the regression coefficients of the three variable production inputs of reliable banks, bank revenue model needs to vbe put some control variables (Bikker, Shaffer, and Spierdijk (2012)). The control variables have a significant influence directly to the level of bank income, thus by the inclusion of this control variable, the regression coefficient of the three input prices will experience the "adjustment" than the model without control variables. Control variables that affect the level of the bank income is bank size, capital structure of the bank, and the bank's risk. These three control variables called Exogenous Factors Specific Bank (BSF).

The first control variables or Bank Specific Exogenous Factor is the total bank assets as a bank size and as a proxy of the economic scale of bank production process. Although banking research literature contains a debate whether a larger bank is likely to become more efficient or just the opposite (Kishan and Opiela, 2000) however almost all researchers agree that the size of the bank greatly affect the level of income of the bank. The next control variable is the adequacy of bank capital that can be captured through the ratio of total equity to total assets. Molyneux (1994) shows the capital ratios significantly affect bank risk taking and profitability of banks. The structure of bank funding is reflected in the ratio of total debt to total assets that also determine the level of bank profitability. The greater the proportion of bank loans, the bank will be more enthusiastic to take risks so that the bank profitability will be higher, on the other hand increases the risk of the bank. Liquidity risk is reflected in the bank cash ratio for each bank to total deposits that affect the level of income for the bank. The last is the control variables of other income. The proportion of other income to total revenue reflects the bank's revenue sources and strategies that should be assumed affects the income level of the bank.

Reduced log-normal function model of bank revenue used to calculate $\mathrm{H}$ statistic as a measure of the degree of competition within the banking industry by Rosse Panzar approach is as follows:

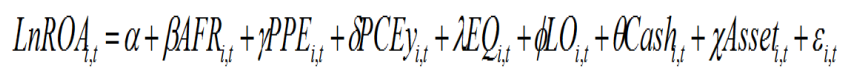



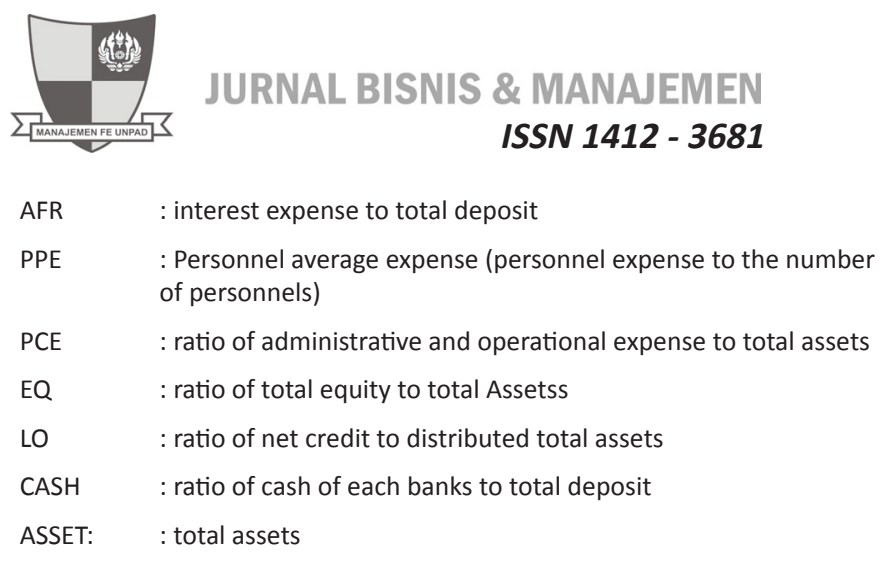

$\mathrm{H}$ statistic value of the Panzar-Rosse is calculated by the fooolowing formula:

$$
\text { H-statistic }=\beta+\gamma+\delta
$$

The coefficient $\beta, \gamma$, and $\delta$ obtained from the estimation of model (3) for data every year so as to obtain a measure of banking competition every year. To conclude the classification level of competitive banking industry of the magnitude $\mathrm{H}$ Panzar Rosse statistical models is using criteria exhibited in Table 5.

Table 5 H-statistic Panzar-Rosse Model Criteria

\begin{tabular}{cc}
\hline $\mathrm{H}$ values & Competition \\
\hline $\mathrm{H} \leq 0$ & Monopoly atau colluted Oligopoly (Cartel) \\
$\mathrm{O}<\mathrm{H}<1$ & Monopolistic competition \\
$\mathrm{H}=1$ & Perfect competition \\
\hline
\end{tabular}

Wald Test is used to test whether the amount of $\mathrm{H}$ statistics generated from the estimated model (3) lies on the two extremes of the spectrum type of competition, monopoly and perfect competition. By using the Wald test, the two null hypothesis can be tested separately ie whether $\beta+\gamma+\delta=0$ which means the competition is monopoly or oligopoly or $\beta$ $+\gamma+\delta=1$, which means the competition are perfectly competitive. Wald statistic measures how close the unrestricted estimates meet the existing restriction on the null hypothesis. If the restriction may be justified empirically, then the unrestricted estimates will approach the restriction of the null hypothesis (Davidson, Russell and MacKinnon (1993)).

\section{Data}

This study uses data from the financial statements of all commercial banks (exclude BPD and BPR) in Indonesia which are actively operating in the period 2000 to 2013. Data from 2000 to 2010 obtained from Bank Indonesia and the data 2010 to 2013 obtained from the Indonesian Financial Services Authority
Jurnal Bisnis \& Manajemen, 2016, Vol. XVII, No. 1, 58-72

(OJK). Additional supporting data relating to banks of other countries used as comprison obtained from Thomson Reuters, World Bank, and the Central Bank in Malaysia, Thailand and the Philippines.

\section{Result}

The result of the bank cost structure differences within inter-group of assets can be seen in the Table 6 . The cost structure of large banks is proved to be more effective than medium-sized and small ones. The efficiency of large banks is evident from the average cost of funds (AFR), large banks are much lower than medium-sized and small ones and consistently every year during the period 2000-2011. Large banks have the ability to withdraw funds cheaper than medium and small ones because it has the advantage of infrastructure such as ATMs and more extensive branch offices making it easier for customers doing the transaction and more attractive cash management for companies so that the customer funds may be withheld and create a large enough and low-cost sediment core deposits. AFR medium-sized banks is higher than the big banks but lower than smaller banks. This is an indication that the magnitude of asset costs as an achievement factor for bank to get funds more cheaply. This indication is getting stronger if we look at the standard deviation of the average cost of funds (AFR) which is quite large among the banks included in the group of large banks. There is tight enough competition among the large banks in the deposit market so that the relatively smaller banks requisite to offer interest rate much higher.

Indications of quite tight market segmentation in Indonesian banking can be seen also from the data in Table 6 that the standard deviation of AFR is large enough for each group of banks. AFR of the large banks at the highest/maximum score even higher than the AFR of medium-sized banks at highest score in some years (2000, 2004 and 2005). The existence of banks that have considerable difference AFR with other banks in the long enough period of time indicates that Indonesian banking market is very segmented, and the competition that can be expected to be more non price competition.

Average personnel costs (PPE) of the large banks is lower than medium-sized banks and small banks. This is an indication that higher technology infrastructure 
in large banks were able to reduce the use of labor more efficiently. The larger the bank's assets, the greater use of information technology thus costs can be reduced. This is reinforced by the decreased average overhead of physical (PCE) incrementally of large banks, medium-sized banks and small banks. The economic scale in the group of small and medium banks have not been achieved. This finding contrasts with the conclusion of Berger and Hannan (1998), however it is much like the latest findings in US and European banks (Kovner, Vickrey and Zhou, 2014 and Beccali, Anolli, and Borello, 2015).

\begin{tabular}{|c|c|c|c|c|c|c|c|c|c|c|c|c|c|c|c|c|c|}
\hline \multirow[b]{2}{*}{ Bank Groups br Size } & \multirow[b]{2}{*}{ Sitatistics } & \multicolumn{4}{|c|}{2000} & \multicolumn{4}{|c|}{2001} & \multicolumn{4}{|c|}{200} & \multicolumn{4}{|c|}{ Wo3 } \\
\hline & & ASSET & AR & $m$ & $\kappa \varepsilon$ & asset & ARR & $m$ & pi & Assit & AR & $m$ Prf & $\mathrm{pQE}$ & assit & Air & $m$ & Mf \\
\hline \multirow[t]{5}{*}{ Bigg } & Average & $26,46,13$ & $86 \%$ & 13.57 & 3.69 & 1380150 & 9746 & 1768 & 1346 & $627,51,661$ & 968 & 1635 & $20 \%$ & $2,48,665$ & $166 \%$ & 180 & $3.45 \%$ \\
\hline & Maximum & 25999988 & $1449 \%$ & 1813 & $913 \%$ & 180,34600 & $1138 \%$ & 170.1 & $63 \%$ & 6.292999 & $1974 \%$ & 1885 & $622 \%$ & $25,81,797$ & $1279 \%$ & 1907 & 8718 \\
\hline & Minimim & $1,67,18$ & $472 \%$ & 169 & 134 & 130,000 & $3,7 \%$ & 1538 & $193 \%$ & 16, 2,17,99. & $27 \%$ & 12.76 & $19 \%$ & 13936.62 & $280 \%$ & 10.10 & $1.1 \%$ \\
\hline & Standard of & 47,92019: & $40 \%$ & 1.077 & $20 \%$ & 4993,47 & 3996 & 104 & $12 \%$ & $60,42 \%$ & $461 \%$ & 1988 & $126 \%$ & $40,2,4382$ & $200 \%$ & 194 & 1518 \\
\hline & Number of Bank & 3 & & & & 31 & & & & 38 & & & & 31 & & & \\
\hline \multirow[t]{5}{*}{ Medium } & Avergge & 95088. & $80 \%$ & 860) & $5.7 \%$ & $1,306,768$ & $866 \%$ & 1902 & $4.9 \%$ & $1,155,260$ & $959 \%$ & 19.12 & $347 \%$ & $1,46,840$ & $6.7 \%$ & 169 & $3 \pi \%$ \\
\hline & Maximum & 1,66695 & $138 \%$ & 38 & $109 \%$ & 2086,144 & 18:4lis & 254. & $16881 \%$ & $2,000,62$ & $209 \%$ & 1568 & $931 \%$ & 154956 & $128 \%$ & 2488 & 9818 \\
\hline & Nimmm & $4,4,4$ & 1144 & 160 & $181 \%$ & 611,83 & $291 \%$ & 1069 & $186 \%$ & 636390 & 366 & 1394 & $11 \%$ & 6i:M & $24 \%$ & 13.4 & 098 \\
\hline & Standard of & 38885 & $29 \%$ & 184 & $83 \%$ & 49999 & $373 \%$ & 802 & $31 \%$ & 41995 & $433 \%$ & 3.17 & $177 \%$ & $3 \times 6,600$ & $268 \%$ & 16.6 & $208 \%$ \\
\hline & Number of Balk & 4 & & & & 3 & & & & ig & & & & 31 & & & \\
\hline \multirow[t]{5}{*}{ Small } & Average & 20288 & $992 \%$ & 2661 & $598 \%$ & 253288 & $115 \%$ & 330 & $501 \%$ & 28812 & $126 \%$ & 41.70 & $668 \%$ & 38,187 & $84 \%$ & 694 & $50 \%$ \\
\hline & Masinum & 41,57 & $1584 \%$ & 20.18 & $963 \%$ & 392,216 & $220 \%$ & 27.17 & $139 \%$ & 335,36 & $2066 \%$ & 2215 & 9346 & $65.9,935$ & $1800 \%$ & 13.17 ! & $10.098 \%$ \\
\hline & Minmum & 1267. & $601 \%$ & 645 & $201 \%$ & 13,349 & $49 \%$ & 1120 & $19 \%$ & 332,26 & $27 \%$ & 1051 & 254 & 30,038 & $461 \%$ & 10.8 & $239 \%$ \\
\hline & Standard of & 11796 & $666 \%$ & 11126 & $36 \%$ & 13,432 & $391 \%$ & 36. & $25 \%$ & 151,35 & 599 & 1728 & $148 \%$ & 16,606 & 3540 & 3.35 & $20 \%$ \\
\hline & Number of Bank & 3 & & & & is & & & & 38 & & & & is & & & \\
\hline
\end{tabular}

\begin{tabular}{|c|c|c|c|c|c|c|c|c|c|c|c|c|c|c|}
\hline \multirow[b]{2}{*}{ Bank Groups by Size } & \multirow[b]{2}{*}{ Statistics } & \multicolumn{4}{|c|}{ WH } & \multicolumn{3}{|c|}{ MS } & \multicolumn{4}{|c|}{ W } & \multicolumn{2}{|r|}{$m$} \\
\hline & & AsS & $A R$ & $m$ & $\mathrm{pl}$ & גes: & \begin{tabular}{l|l} 
AR & m \\
\end{tabular} & $\mathrm{KL}$ & As: & An & \begin{tabular}{|l|l|l|}
$m$ & \\
\end{tabular} & 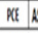 & 속 & 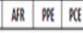 \\
\hline \multirow[t]{5}{*}{ Big } & Average & 0,68021 & 464 & & 海 & $14+498$ & 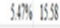 & 1364 & $19489 \%$ & $10 \%$ & 184 & 366 & 4616,60 & 5716098 i.t. \\
\hline & Maximum & 20682020 & 816 & & 199 & 31,2912 & 98236 & $80 \%$ & 282111117 & $126 \%$ & 8.6 & $673 \%$ : & 306,6280 & 91560468. \\
\hline & Minimum & iLin & 13 W & & 125 & 1,4068 & $20 \% 128$. & 1. 15 & 6.3.4. & & 30 & ONh & $1,4,4,61$ & 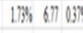 \\
\hline & Standard of & 4,6225 & $19 \pi$ & & $16 \%$ & 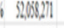 & $196510 \%$ & 1.6 & 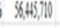 & $2 \%$ & 124 & $12 \%$ & 6.69:68 & 165615458 \\
\hline & Number of Bank & i) & & & & i1 & & & i1] & & & & i) & \\
\hline \multirow[t]{5}{*}{ Medim } & Average & 1866110 & 460 & 1957 & $40 \%$ & 13199 & 38969 & 138 & 1987,16 & 132 & 1162 & $3 \%$ & $3,36.264$ & 60617233 \\
\hline & Maximum & 淠:36 & BLK & 185.7 & $91 \%$ & 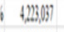 & 92151898 & 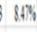 & 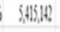 & & 61212 & $13 \%$ & $6,693.34$ & 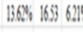 \\
\hline & Mimimum & 8591 & 160 & & 06\% & 1,$66 ; 0$ & 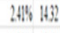 & : 194 & 13966 & Wh & 106 & 065i & 159,13 & LIIS DMS 0.4 \\
\hline & Standard of & 49 & $16 \%$ & 1,18 & $1 \%$ & $60.13 \%$ & $10 \% 884$ & 160 & 1200,115 & $29 \%$ & 180 & LWN & byom & 2656969 \\
\hline & Number of Bank & i) & & & & 3) & & & in & & & & i) & \\
\hline \multirow[t]{5}{*}{ Small } & Average & 5646 & $49 \%$ & & 3 ho & 45416 & 605 199: & $14 \%$ & 3610 & & 129 & $468 \%$ & 72,18 & 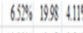 \\
\hline & Maximum & 88,34 & 993 & & 1085 & $1,06,16$ & $95 \times 218$ & 61038 & 199909 & 13:4h & $168:$ & $104 \%$ & $1,30,1,6$ & 102812.6844 \\
\hline & Mimimum & $21 \%$ & 212 & & $1 \%$ & 6224 & 1693133 & $20 \%$ & 7081 & & 1360 & OSW & 19,06 & $20 \% 60908$ \\
\hline & Standard of & MOS? & $18 \%$ & 300 & $40 \%$ & 2002 & 201589 & 112 & 340 & 244 & ilit) & $16 \%$ & 18:67 & 2008133160 \\
\hline & Number of $B$ ank & $x$ & & & & 3 & & & $x$ & & & & 38 & \\
\hline
\end{tabular}

\begin{tabular}{|c|c|c|c|c|c|c|c|c|c|c|c|c|c|c|c|c|}
\hline \multirow{3}{*}{ Bank Groups by Size } & \multirow[b]{3}{*}{ Statistics } & \multirow{2}{*}{\multicolumn{4}{|c|}{ W }} & \multirow{2}{*}{\multicolumn{3}{|c|}{$M$}} & \multirow{2}{*}{\multicolumn{4}{|c|}{ (WiN) }} & \multirow{2}{*}{\multicolumn{4}{|c|}{2011}} \\
\hline & & & & & & & & & & & & & & & & \\
\hline & & As: & HR & $m$ & KI NS & As:STI & \begin{tabular}{|l|l|} 
AR & 1 \\
\end{tabular} & \begin{tabular}{l|l|}
$m$ & $k$ \\
\end{tabular} & Kf kssit & HR & m & Mi $\mathrm{NS}$ & AMST & HI & $m$ & $n g$ \\
\hline \multirow[t]{5}{*}{ Bigg } & Average & 4660 & $37 \%$ & 1909 & $3+45$ & $469,9 !$ & $36 \%$ & 17613 & $66 \%$ 6): & 686139 & 199 & 368 & $60,36,686$ & $613 \%$ & 293 & 30. \\
\hline & Maximum & 隹, 638 & 9114 & $10 \mathrm{H}$ & $68 \mathrm{M}$ & 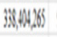 & $9 \%$ & 134318 & 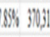 & 13 1354 & 186 & $738 \mathrm{i}$ & $3130 \%$ & 1344 & 180 & 135. \\
\hline & Minimum & $1,43,6$ & $17 \%$ & 16.7 & 0.3 & 18699 & $24 \pi$ & 3850 & 1086102 & If $29 \%$ & 48 & 09\% & 11031,165 & $2 \%$ & 300 & $09 \%$ \\
\hline & Standard of & 676394 & $16 \%$ & in: & $15 \%$ & 17,W46, & $17 \pi$ & (9) 18 & $130 \% N B$ & is 13 & 138 & Lith & 808968 & 36 & 84 & L.t. \\
\hline & Number of $B$ ank & 3 & & & & 3 & & & & 3) & & & 3) & & & \\
\hline \multirow[t]{5}{*}{ Medium } & Averags & 3 3is. & & 178 & 339 & 1,WW:? & $6 \%$ & 187338 & $3 \% 46$ & $60 \%$ & 178 & 339 & intis & $60 \%$ & $17 \%$ & $33 x^{2}$ \\
\hline & Maximum & 607358 & & 1659 & 6145 & 83994. & H.H & 14888 & $9 \% 9$ & and 989 & 100 & $6+94$ & 10,59190 & $98 \%$ & & $6+5$ \\
\hline & Minimum & 1605 & 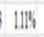 & 300 & $04 \%$ & 18490 & 124 & 3994 & 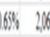 & W. $34 \%$ & 1.487 & $07 \%$ & 21095 & $36 \%$ & 38 & 1084 \\
\hline & Standard of & 1598 & 1246 & 169 & $14^{4}$ & 19861616 & $29 \%$ & 1841 & $18 \% 4,46$ & 61 $21 \%$ & 111 & Bith & 16012 & $21 \%$ & 1811. & 154 \\
\hline & Number of Bank & 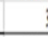 & & & & i) & & & & in & & & i) & & & \\
\hline \multirow[t]{5}{*}{ Small } & Average & & $62 \%$ & 199 & 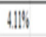 & 826 & 869 & $199 !$ & 1798 & 40 & 30 & 368 & & 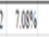 & MIN & 368 \\
\hline & Masimum & BS1, & & 1247 & 854 & $1,81,93$. & $8 \% 4$ & & & 7]1 $163 \%$ & & 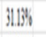 & $4111,1 \%$ & 61439 & & 3113 \\
\hline & Minmum & 194,0 & 6 濼 & DOM & Q04 & 161,30 & $286:$ & MI! ! & $2 W$ & is & 811 & $20 \%$ & Witis & is & 611 & $20 \%$ \\
\hline & Standard of & Bit, & $120 \%$ & 135 & $16 \%$ & 51940 & th & 8132 & $2 W$ & $5 \times 25 \%$ & 153 & 30\% & & $826 \%$ & 150 & 5031 \\
\hline & Number of Bank & 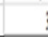 & & & & is & & & & 3 & & & is & & & \\
\hline
\end{tabular}

$\mathrm{AFR}=$ Average Funding Rate $\mathrm{PPE}=$ Price of Personeel
Expenses, $\mathrm{PCE}=$ Price of Capital Expenses

To understand the differences in the cost structure incurred amongst the large banks, medium-sized banks and small banks, we need to measure the concentration and competition among banks within every group of banks. The results of concentration measurements in the Indonesian banking industry by a group of banks can be seen in Table 7, Table 8 and Table 9. Concentration of the asset and the DPK on large banks observed is always greater than the concentration of the Credit, competition in the deposit market is dominated by several large bank. The same thing does not happen to the group of small banks. This dominance instigates the considerable difference in the cost of funds (AFR) of the large banks. The level of competition in the group of large banks also proved quite low and close to oligopoly while small banks group competition leads to monopolistic competition, as it will be discussed later (Table 10). Competition which is relatively low and leads to oligopoly in the credit market banks of the large bank group led to the bank with higher cost of funds are still able to exist in the long term. The concentration from the DPK perspectives that higher than the concentration of the Credit at a large bank group disignates the intermediation function in large banks is not optimum yet.

Table 7 Large Bank Concentration in Indonesia 2000 -2012

\begin{tabular}{cccccccccc}
\hline Year & $\begin{array}{c}\text { CR3 } \\
\text { Assets }\end{array}$ & $\begin{array}{c}\text { CR5 } \\
\text { Assets }\end{array}$ & $\begin{array}{c}\text { IHH } \\
\text { Assets }\end{array}$ & $\begin{array}{c}\text { CR3 } \\
\text { Credit }\end{array}$ & $\begin{array}{c}\text { CR5 } \\
\text { Credit }\end{array}$ & $\begin{array}{c}\text { IHH } \\
\text { Credit }\end{array}$ & $\begin{array}{c}\text { CR3 } \\
\text { DPK }\end{array}$ & $\begin{array}{c}\text { CR5 } \\
\text { DPK }\end{array}$ & $\begin{array}{c}\text { IHH } \\
\text { DPK }\end{array}$ \\
\hline 2000 & 0.536 & 0.684 & 0.136 & 0.463 & 0.609 & 0.096 & 0.550 & 0.683 & 0.130 \\
2001 & 0.565 & 0.712 & 0.143 & 0.398 & 0.571 & 0.095 & 0.565 & 0.709 & 0.137 \\
2002 & 0.558 & 0.709 & 0.137 & 0.494 & 0.631 & 0.107 & 0.561 & 0.714 & 0.135 \\
2003 & 0.544 & 0.702 & 0.129 & 0.487 & 0.631 & 0.104 & 0.546 & 0.705 & 0.125 \\
2004 & 0.518 & 0.681 & 0.118 & 0.479 & 0.638 & 0.102 & 0.538 & 0.692 & 0.121 \\
2005 & 0.479 & 0.644 & 0.106 & 0.442 & 0.609 & 0.094 & 0.496 & 0.654 & 0.110 \\
2006 & 0.462 & 0.642 & 0.101 & 0.435 & 0.603 & 0.093 & 0.489 & 0.669 & 0.109 \\
2007 & 0.477 & 0.654 & 0.105 & 0.430 & 0.605 & 0.091 & 0.504 & 0.678 & 0.112 \\
2008 & 0.461 & 0.630 & 0.099 & 0.427 & 0.607 & 0.092 & 0.489 & 0.666 & 0.108 \\
2009 & 0.485 & 0.652 & 0.105 & 0.454 & 0.633 & 0.099 & 0.514 & 0.691 & 0.115 \\
2010 & 0.480 & 0.650 & 0.107 & 0.448 & 0.626 & 0.095 & 0.503 & 0.688 & 0.108 \\
2011 & 0.476 & 0.642 & 0.102 & 0.438 & 0.618 & 0.090 & 0.491 & 0.681 & 0.104 \\
2012 & 0.468 & 0.640 & 0.09 & 0.430 & 0.602 & 0.086 & 0.482 & 0.675 & 0.101 \\
\hline
\end{tabular}

In the group of large banks, observed from CR3, CR5, and $\mathrm{IHH}$ in terms of Assets, Credit, as well as third party funds is is generally not concentrated gradually. In CR3 Assets, the highest rates occur in the year 2000 
with a value of 0.536 and the lowest number occurred in the year 2008 with a value of 0.461 . In the year 2009 , there was slightly increased to 0.485 . The same thing happened in CR5 Assets, where the highest concentrations occured in the year 2000 with a value of 0.683 while the lowest concentration occured in the year 2008 with a value of 0.630 . $\mathrm{IHH}$ assets is not much different either, where the highest IHH Assets was in the year 2000 with a value of 0,138 while the lowest occurred in year 2008 with a value of 0.099 .

Table 8 Medium Banks Concentration in Indonesia2000-2012

\begin{tabular}{cccccccccc}
\hline Year & $\begin{array}{c}\text { CR3 } \\
\text { Assets }\end{array}$ & $\begin{array}{c}\text { CR5 } \\
\text { Assets }\end{array}$ & $\begin{array}{c}\text { IHH } \\
\text { Assets }\end{array}$ & $\begin{array}{c}\text { CR3 } \\
\text { Credit }\end{array}$ & $\begin{array}{c}\text { CR5 } \\
\text { Credit }\end{array}$ & $\begin{array}{c}\text { IHH } \\
\text { Credit }\end{array}$ & $\begin{array}{c}\text { CR3 } \\
\text { DPK }\end{array}$ & $\begin{array}{c}\text { CR5 } \\
\text { DPK }\end{array}$ & $\begin{array}{c}\text { IHH } \\
\text { DPK }\end{array}$ \\
\hline 2000 & 0.202 & 0.285 & 0.032 & 0.207 & 0.309 & 0.036 & 0.180 & 0.273 & 0.030 \\
2001 & 0.221 & 0.328 & 0.036 & 0.225 & 0.332 & 0.037 & 0.198 & 0.307 & 0.033 \\
2002 & 0.183 & 0.284 & 0.031 & 0.197 & 0.284 & 0.033 & 0.214 & 0.303 & 0.034 \\
2003 & 0.187 & 0.285 & 0.030 & 0.181 & 0.270 & 0.032 & 0.207 & 0.313 & 0.033 \\
2004 & 0.174 & 0.265 & 0.028 & 0.172 & 0.261 & 0.030 & 0.199 & 0.296 & 0.031 \\
2005 & 0.169 & 0.271 & 0.030 & 0.189 & 0.276 & 0.031 & 0.187 & 0.292 & 0.032 \\
2006 & 0.158 & 0.252 & 0.029 & 0.165 & 0.254 & 0.029 & 0.183 & 0.288 & 0.033 \\
2007 & 0.161 & 0.249 & 0.029 & 0.188 & 0.279 & 0.032 & 0.174 & 0.264 & 0.031 \\
2008 & 0.157 & 0.240 & 0.029 & 0.171 & 0.260 & 0.031 & 0.175 & 0.263 & 0.031 \\
2009 & 0.175 & 0.255 & 0.030 & 0.168 & 0.252 & 0.030 & 0.193 & 0.281 & 0.032 \\
2010 & 0.170 & 0.250 & 0.028 & 0.164 & 0.250 & 0.028 & 0.187 & 0.276 & 0.030 \\
2011 & 0.168 & 0.243 & 0.026 & 0.160 & 0.249 & 0.025 & 0.181 & 0.251 & 0.029 \\
2012 & 0.160 & 0.240 & 0.025 & 0.157 & 0.245 & 0.023 & 0.175 & 0.250 & 0.026 \\
\hline
\end{tabular}

In the group of medium-sized banks, observed from CR3, CR5, and IHH in terms of the Assets, Credit, as well as third party funds is generally not concentrated gradually. Unlike the group of large banks, in terms of asset concentration of medium-sized banks in deposits is lower than the concentration of the Credit. This signifies that competition in the deposit market within the group of medium-sized banks are relatively more distributed equally. The same thing happened to a group of small banks like the one in Table 9.

Table 9 Small Bank Concentration in Indonesia 2000 -2012

\begin{tabular}{cccccccccc}
\hline Year & $\begin{array}{c}\text { CR3 } \\
\text { Assets }\end{array}$ & $\begin{array}{c}\text { CR5 } \\
\text { Assets }\end{array}$ & $\begin{array}{c}\text { IHH } \\
\text { Assets }\end{array}$ & $\begin{array}{c}\text { CR3 } \\
\text { Credit }\end{array}$ & $\begin{array}{c}\text { CR5 } \\
\text { Credit }\end{array}$ & $\begin{array}{c}\text { IHH } \\
\text { Credit }\end{array}$ & $\begin{array}{c}\text { CR3 } \\
\text { DPK }\end{array}$ & $\begin{array}{c}\text { CR5 } \\
\text { DPK }\end{array}$ & $\begin{array}{c}\text { IHH } \\
\text { DPK }\end{array}$ \\
\hline 2000 & 0.250 & 0.354 & 0.044 & 0.460 & 0.547 & 0.115 & 0.223 & 0.344 & 0.042 \\
2001 & 0.191 & 0.295 & 0.037 & 0.235 & 0.350 & 0.044 & 0.186 & 0.279 & 0.037 \\
2002 & 0.168 & 0.266 & 0.035 & 0.205 & 0.314 & 0.041 & 0.183 & 0.279 & 0.037 \\
2003 & 0.166 & 0.258 & 0.035 & 0.181 & 0.288 & 0.040 & 0.174 & 0.271 & 0.036 \\
2004 & 0.187 & 0.279 & 0.036 & 0.197 & 0.300 & 0.040 & 0.203 & 0.302 & 0.038 \\
2005 & 0.183 & 0.276 & 0.036 & 0.193 & 0.300 & 0.039 & 0.203 & 0.300 & 0.039 \\
2006 & 0.182 & 0.288 & 0.037 & 0.198 & 0.299 & 0.039 & 0.195 & 0.304 & 0.039 \\
2007 & 0.174 & 0.275 & 0.036 & 0.203 & 0.308 & 0.040 & 0.195 & 0.305 & 0.039 \\
\hline
\end{tabular}

Continue of Table 9 Small Bank Concentration in Indonesia $2000-2012$

\begin{tabular}{cccccccccc}
\hline Year & $\begin{array}{c}\text { CR3 } \\
\text { Assets }\end{array}$ & $\begin{array}{c}\text { CR5 } \\
\text { Assets }\end{array}$ & $\begin{array}{c}\text { IHH } \\
\text { Assets }\end{array}$ & $\begin{array}{c}\text { CR3 } \\
\text { Credit }\end{array}$ & $\begin{array}{c}\text { CR5 } \\
\text { Credit }\end{array}$ & $\begin{array}{c}\text { IHH } \\
\text { Credit }\end{array}$ & $\begin{array}{c}\text { CR3 } \\
\text { DPK }\end{array}$ & $\begin{array}{c}\text { CR5 } \\
\text { DPK }\end{array}$ & $\begin{array}{c}\text { IHH } \\
\text { DPK }\end{array}$ \\
\hline 2008 & 0.177 & 0.276 & 0.037 & 0.211 & 0.321 & 0.040 & 0.193 & 0.300 & 0.040 \\
2009 & 0.238 & 0.337 & 0.042 & 0.252 & 0.354 & 0.046 & 0.242 & 0.361 & 0.044 \\
2010 & 0.231 & 0.338 & 0.037 & 0.242 & 0.335 & 0.041 & 0.235 & 0.301 & 0.043 \\
2011 & 0.227 & 0.331 & 0.032 & 0.230 & 0.312 & 0.036 & 0.192 & 0.282 & 0.042 \\
2012 & 0.224 & 0.326 & 0.030 & 0.221 & 0.302 & 0.031 & 0.180 & 0.272 & 0.040 \\
\hline
\end{tabular}

In the group of small banks, the concentration is generally experienced a declining pattern. However even it is more industry concentration, competition in the group of small banks are even more stringent than in other bank groups. Competition in the small banks proved to be more stringent as will be discussed later (Table 14).

The level of competition in the major bank groups in the year 2000 to 2012 as measured by Panzar-Rosse competition model can be seen in Table 10. Summary of the results of competition measurement on large bank group and the results of the Wald test of $\mathrm{H}$ Panzar-Rosse statistic model can be seen in Table 11. The results of the competition Panzar-Rosse model estimation of medium-sized banks and small banks are not reported in this paper and is only a summary of the results considering conciseness of the page, and canbe convey by the author upon request.

Table 10 Estimation Result of Panzar-Rosse Competition Model on Large Banks
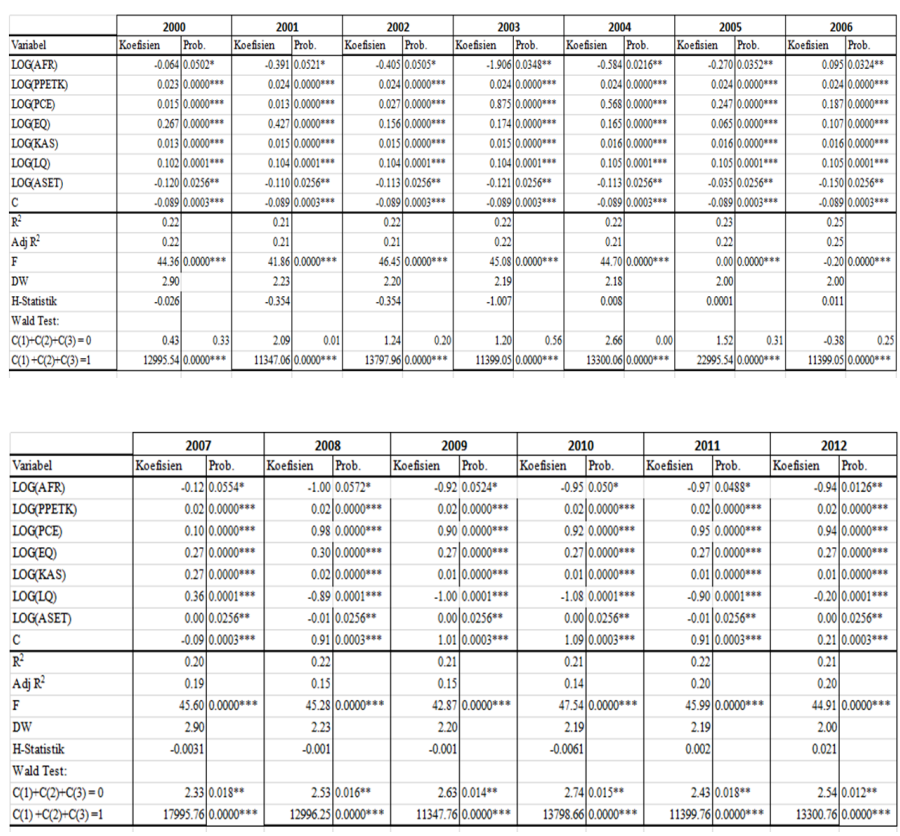

*significant with $10 \%$ degree of error, ** significant with $5 \%$ 
degree of error, ${ }^{* * *}$ significant with $1 \%$ degree of error

Table $11 \mathrm{H}$-statistic value of Panzar-Rosse and Competition Type in Large Bank Group

\begin{tabular}{|c|c|c|c|c|c|}
\hline \multirow{2}{*}{ Year } & \multirow{2}{*}{ H-Stat } & \multicolumn{2}{|c|}{ Wald Test } & & \multirow{2}{*}{$\begin{array}{l}\text { Maket Structure/ } \\
\text { Competition Type }\end{array}$} \\
\hline & & Hyphothesis & prob & & \\
\hline \multirow[t]{2}{*}{2000} & -0.026 & $\mathrm{H}$-Stat $=0$ & 0.466 & & Colluted oligopoly \\
\hline & & $\mathrm{H}$-Stat = 1 & 0.000 & $* * *$ & \\
\hline \multirow[t]{2}{*}{2001} & -0.354 & H-Stat $=0$ & 0.018 & $* *$ & monopolistic \\
\hline & & $\mathrm{H}$-Stat $=1$ & 0.000 & $* * *$ & \\
\hline \multirow[t]{2}{*}{2002} & -0.354 & $\mathrm{H}$-Stat $=0$ & 0.309 & & Colluted oligopoly \\
\hline & & $\mathrm{H}$-Stat $=1$ & 0.000 & $* * *$ & \\
\hline \multirow[t]{2}{*}{2003} & -1.007 & $\mathrm{H}$-Stat $=0$ & 0.379 & & Colluted oligopoly \\
\hline & & $\mathrm{H}$-Stat $=1$ & 0.000 & $* * *$ & \\
\hline \multirow[t]{2}{*}{2004} & 0.008 & $\mathrm{H}$-Stat $=0$ & 0.779 & & Colluted oligopoly \\
\hline & & $\mathrm{H}$-Stat = 1 & 0.000 & $* * *$ & colluted oligopoly \\
\hline \multirow[t]{2}{*}{2005} & 0.000 & $\mathrm{H}$-Stat $=0$ & 0.981 & & Colluted oligopoly \\
\hline & & H-Stat = 1 & 0.000 & $* * *$ & \\
\hline \multirow[t]{2}{*}{2006} & 0.011 & $\mathrm{H}$-Stat $=0$ & 0.434 & & Colluted oligopoly \\
\hline & & H-Stat $=1$ & 0.000 & $* * *$ & \\
\hline \multirow[t]{2}{*}{2007} & -0.003 & $\mathrm{H}$-Stat $=0$ & 0.862 & & Colluted oligopoly \\
\hline & & $\mathrm{H}$-Stat $=1$ & 0.000 & $* * *$ & \\
\hline \multirow[t]{2}{*}{2008} & -0.001 & $\mathrm{H}$-Stat $=0$ & 0.936 & & Colluted oligopoly \\
\hline & & H-Stat $=1$ & 0.000 & $* * *$ & \\
\hline \multirow[t]{2}{*}{2009} & -0.001 & $\mathrm{H}$-Stat $=0$ & 0.046 & $* *$ & monopolistic \\
\hline & & $\mathrm{H}$-Stat = 1 & 0.000 & $* * *$ & \\
\hline \multirow[t]{2}{*}{2010} & -0.006 & H-Stat $=0$ & 0.687 & & Colluted oligopoly \\
\hline & & $\mathrm{H}$-Stat = 1 & 0.000 & $* * *$ & \\
\hline \multirow[t]{2}{*}{2011} & 0.022 & $\mathrm{H}$-Stat $=0$ & 0.179 & & Colluted oligopoly \\
\hline & & H-Stat $=1$ & 0.000 & $* * *$ & \\
\hline \multirow[t]{2}{*}{2012} & 0.021 & $\mathrm{H}$-Stat $=0$ & 0.199 & & Colluted oligopoly \\
\hline & & $\mathrm{H}$-Stat $=1$ & 0.000 & $* * *$ & \\
\hline
\end{tabular}

*significant with $10 \%$ degree of error, ${ }^{* *}$ significant with $5 \%$ degree of error, ***significant with $1 \%$ degree of error

Source: Data processing attachment

Competition pattern in a group of large and medium banks in Indonesia are not much different from the applied pattern of competition in the whole / the Indonesian banking industry (Wibowo, 2015), that is colluted oligopoly market structure although there are some year the pattern in which competition is monopolistic with the $\mathrm{H}$-statistic value -0.354 and year 2006 with $\mathrm{H}$-statistic value -0.001 in the group of large banks. Competition in the group of mediumsized banks began to lead towards monopolistic competition in the last two observations year 2011 and 2012.

The level of competition in Indonesian banking industry is away from the level of competition in neighboring countries like Malaysia, Thailand and the Philippines. Based on World Bank on the Global Financial Development Database, the level of banking competition in Malaysia, Thailand, and the Philippines are quite strict with quite high PanzarRosse $\mathrm{H}$ statistic as can be seen in Table 12A. This finding further strengthens indications that the concentration may not reflect the level of banking competition due to the concentration ratio of the three countries, as can be seen in Table 12B, much higher than the concentration ratio in Indonesia. If high concentrations trigger much loose competition, the competition in the three countries should be far more lax with lower H statistic.

Table 12.A H statistic Panzar Rosse Malaysia, Thailand, and the Filipina

\begin{tabular}{cccc}
\hline & Malaysia & Thailand & Philippines \\
\hline 2010 & 0,66 & 0,67 & 0,72 \\
\hline Source: Global Financial Development Database, & World Bank
\end{tabular}

Table 12.B Concentration Ratio Malaysia, Thailand and the Philippines Banking

\begin{tabular}{ccccccc}
\hline & \multicolumn{3}{c}{ CR3 Asset } & \multicolumn{3}{c}{ CR5 Asset } \\
\cline { 2 - 7 } & Malaysia & Thailand & Philippines & Malaysia & Thailand & Philippines \\
\hline 1999 & 46.18 & 49.03 & 80.16 & 56.51 & 68.00 & 94.44 \\
2000 & 50.27 & 49.69 & 100.00 & 62.22 & 68.66 & 93.90 \\
2001 & 46.31 & 48.44 & 99.68 & 56.82 & 67.08 & 93.70 \\
2002 & 46.06 & 48.66 & 98.97 & 56.46 & 66.98 & 92.06 \\
2003 & 45.75 & 49.22 & 98.77 & 56.60 & 67.83 & 90.58 \\
2004 & 47.76 & 47.15 & 73.43 & 59.44 & 67.11 & 87.51 \\
2005 & 49.56 & 44.17 & 41.26 & 62.25 & 64.02 & 58.68 \\
2006 & 55.04 & 44.75 & 39.60 & 66.49 & 65.28 & 57.11 \\
2007 & 54.60 & 45.83 & 49.97 & 66.49 & 65.17 & 68.60 \\
2008 & 54.51 & 45.11 & 47.49 & 66.87 & 66.23 & 65.05 \\
2009 & 55.28 & 46.73 & 46.67 & 67.10 & 67.51 & 64.44 \\
2010 & 54.19 & 47.78 & 47.57 & 66.34 & 68.98 & 64.99 \\
2011 & 48.85 & 48.24 & 51.54 & 63.69 & 69.09 & 71.04 \\
Rata- & 50.34 & 47.29 & 67.32 & 62.10 & 67.07 & 77.09 \\
rata & & & & & &
\end{tabular}

Source: World Bank

Table 13 H-statisic Value of Panzar-Rosse and Medium Bank Competition

\begin{tabular}{cccccc}
\hline & H-Stat & \multicolumn{2}{c}{ Wald Test } & & Market Structure \\
\cline { 3 - 4 } & & Hypothesis & prob & & \\
\hline \multirow{2}{*}{2000} & 0.026 & H-Stat $=0$ & 0.466 & & colluted oligopoly \\
& & H-Stat $=1$ & 0.000 & $* * *$ & \\
\hline
\end{tabular}




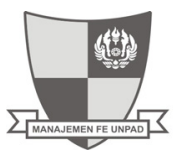

JURNAL BISNIS \& MANAJEMEN

ISSN 1412 - 3681

Continue of Table $13 \mathrm{H}$-statisic Value of Panzar-Rosse and Medium Bank Competition

\begin{tabular}{|c|c|c|c|c|c|}
\hline & \multirow[t]{2}{*}{ H-Stat } & \multicolumn{2}{|c|}{ Wald Test } & & \multirow[t]{2}{*}{ Market Structure } \\
\hline & & Hypothesis & prob & & \\
\hline 2000 & 0.026 & $\mathrm{H}$-Stat $=0$ & 0.466 & & colluted oligopoly \\
\hline \multirow[t]{2}{*}{2001} & 0.014 & $\mathrm{H}$-Stat $=0$ & 0.000 & $* * *$ & monopolistic \\
\hline & & $\mathrm{H}$-Stat $=1$ & 0.000 & $* * *$ & \\
\hline \multirow[t]{2}{*}{2002} & -0.012 & $\mathrm{H}$-Stat $=0$ & 0.488 & & colluted oligopoly \\
\hline & & $\mathrm{H}$-Stat $=1$ & 0.000 & $* * *$ & \\
\hline \multirow[t]{2}{*}{2003} & -0.019 & $\mathrm{H}$-Stat $=0$ & 0.017 & & colluted oligopoly \\
\hline & & H-Stat $=1$ & 0.000 & $* * *$ & \\
\hline \multirow[t]{2}{*}{2004} & -0.039 & $\mathrm{H}$-Stat $=0$ & 0.024 & & colluted oligopoly \\
\hline & & $\mathrm{H}$-Stat = 1 & 0.000 & $* * *$ & \\
\hline \multirow[t]{2}{*}{2005} & -0.010 & $\mathrm{H}$-Stat $=0$ & 0.265 & & colluted oligopoly \\
\hline & & H-Stat $=1$ & 0.000 & $* * *$ & \\
\hline \multirow[t]{2}{*}{2006} & 0.021 & $\mathrm{H}$-Stat $=0$ & 0.149 & & colluted oligopoly \\
\hline & & $\mathrm{H}$-Stat $=1$ & 0.000 & $* * *$ & \\
\hline \multirow[t]{2}{*}{2007} & -0.001 & $\mathrm{H}$-Stat $=0$ & 0.910 & & colluted oligopoly \\
\hline & & $\mathrm{H}$-Stat $=1$ & 0.000 & $* * *$ & \\
\hline \multirow[t]{2}{*}{2008} & -0.005 & $\mathrm{H}$-Stat $=0$ & 0.596 & & colluted oligopoly \\
\hline & & $\mathrm{H}$-Stat = 1 & 0.000 & $* * *$ & \\
\hline \multirow[t]{2}{*}{2009} & 0.001 & $\mathrm{H}$-Stat $=0$ & 0.949 & & colluted oligopoly \\
\hline & & H-Stat $=1$ & 0.000 & $* * *$ & \\
\hline \multirow[t]{2}{*}{2010} & 0.011 & $\mathrm{H}$-Stat $=0$ & 0.753 & & colluted oligopoly \\
\hline & & $\mathrm{H}$-Stat = 1 & 0.000 & $* * *$ & \\
\hline \multirow[t]{2}{*}{2011} & 0.020 & $\mathrm{H}$-Stat $=0$ & 0.027 & & monopolistic \\
\hline & & $\mathrm{H}$-Stat = 1 & 0.000 & $* * *$ & \\
\hline \multirow[t]{2}{*}{2012} & 0.020 & $\mathrm{H}$-Stat $=0$ & 0.023 & & monopolistic \\
\hline & & H-Stat $=1$ & 0.000 & $* * *$ & \\
\hline
\end{tabular}

*significant with 10\% degree of error, **significant with 5\% degree of error, ***significant with $1 \%$ degree of error Source : Data processing attachment

In the group of medium-sized banks, the colluted oligopoly competition pattern, and monopolistic competition, although there are differences in the competition pattern of the different year. Table 4.11 shows that the competition pattern in groups of medium-sized banks in Indonesia based on the value of Panzar-Rosse H-statistic during the period 20002012 was dominated by oligopoly competition. In year 2001, 2011, and 2012 medium-sized banks was monopolistic competition. In addition to the above years competitiomedium asset banks in Indonesia was colluted oligopoly, the year 2000, 2003, 2004, 2005, 2006, 2007, and 2008 with the $\mathrm{H}$-statistic value of each -0.026 in 1998 in $2000-0.012,-1.010$ in 2003 0,021 in 2004 in $2005-0.01,-0.005$ in 2006 0,001 in 2007, and 0,011 in 2008.
Jurnal Bisnis \& Manajemen, 2016, Vol. XVII, No. 1, 58-72

Table 14 H-statisic Value of Panzar-Rosse and Small Bank Competition

\begin{tabular}{|c|c|c|c|c|c|}
\hline & \multirow[t]{2}{*}{ H-Stat } & \multicolumn{2}{|c|}{ Wald Test } & & \multirow[t]{2}{*}{ Market Structure } \\
\hline & & Hypothesis & Prob & & \\
\hline \multirow[t]{2}{*}{2000} & 0.076 & $\mathrm{H}$-Stat $=0$ & 0.446 & & colluted oligopoly \\
\hline & & $\mathrm{H}-\mathrm{Stat}=1$ & 0.000 & $* * *$ & \\
\hline \multirow[t]{2}{*}{2001} & 0.171 & $\mathrm{H}$-Stat $=0$ & 0.060 & $*$ & monopolistic \\
\hline & & $\mathrm{H}-$ Stat $=1$ & 0.000 & $* * *$ & \\
\hline \multirow[t]{2}{*}{2002} & -0.095 & $\mathrm{H}$-Stat $=0$ & 0.002 & $* * *$ & monopolistic \\
\hline & & $\mathrm{H}$-Stat $=1$ & 0.000 & $* * *$ & \\
\hline \multirow[t]{2}{*}{2003} & 0.078 & $\mathrm{H}$-Stat $=0$ & 0.069 & $*$ & monopolistic \\
\hline & & $\mathrm{H}$-Stat $=1$ & 0.000 & $* * *$ & \\
\hline \multirow[t]{2}{*}{2004} & 0.002 & $\mathrm{H}$-Stat $=0$ & 0.979 & & colluted oligopoly \\
\hline & & $\mathrm{H}$-Stat $=1$ & 0.000 & $* * *$ & \\
\hline \multirow[t]{2}{*}{2005} & 0.023 & $\mathrm{H}$-Stat $=0$ & 0.193 & & colluted oligopoly \\
\hline & & $\mathrm{H}$-Stat $=1$ & 0.000 & $* * *$ & \\
\hline \multirow[t]{2}{*}{2006} & 0.027 & $\mathrm{H}$-Stat $=0$ & 0.039 & $* *$ & monopolistic \\
\hline & & $\mathrm{H}$-Stat $=1$ & 0.000 & $* * *$ & \\
\hline \multirow[t]{2}{*}{2007} & -0.036 & $\mathrm{H}$-Stat $=0$ & 0.261 & & colluted oligopoly \\
\hline & & $\mathrm{H}$-Stat $=1$ & 0.000 & $* * *$ & \\
\hline \multirow[t]{2}{*}{2008} & -0.001 & $\mathrm{H}$-Stat $=0$ & 0.901 & & colluted oligopoly \\
\hline & & $\mathrm{H}$-Stat $=1$ & 0.000 & $* * *$ & \\
\hline \multirow[t]{2}{*}{2009} & 0.009 & $\mathrm{H}$-Stat $=0$ & 0.238 & & colluted oligopoly \\
\hline & & $\mathrm{H}$-Stat $=1$ & 0.000 & $* * *$ & \\
\hline \multirow[t]{2}{*}{2010} & -0.066 & $\mathrm{H}$-Stat $=0$ & 0.001 & $* * *$ & monopolistic \\
\hline & & $\mathrm{H}$-Stat $=1$ & 0.000 & $* * *$ & \\
\hline \multirow[t]{2}{*}{2011} & -0.140 & $\mathrm{H}$-Stat $=0$ & 0.000 & $* * *$ & monopolistic \\
\hline & & $\mathrm{H}$-Stat $=1$ & 0.000 & $* * *$ & \\
\hline \multirow[t]{2}{*}{2012} & 0.146 & $\mathrm{H}$-Stat $=0$ & 0.000 & $* * *$ & monopolistic \\
\hline & & $\mathrm{H}$-Stat $=1$ & 0.000 & $* * *$ & \\
\hline
\end{tabular}

*significant with $10 \%$ degree of error, ${ }^{* *}$ significant with $5 \%$ degree of error, ${ }^{* * *}$ significant with $1 \%$ degree of error

Source : Data processing attachment

The group of small banks demonstrates the competition pattern is a little different with the applied competition pattern of all banks, large banks group, or a group of medium-sized banks. In the group of small banks, there is no dominant competition pattern between monopolistic and oligopolistic competition. From Table 4:12 observed that there are 6 years out of 12 years of studies that follow monopolistic competition, while the rest or 6 year following the pattern of equilibrium monopolistic competition/colluted oligopoly. Nonetheless the last three years observed indicates the direction of competition among small banks towards monopolistic competition. 


\section{CONCLUSION}

The structure of bank charges differ among the groups of large banks, medium-sized and small ones. The greater the asset in the bank charges structure, the more efficient the bank is where the average cost of funds, HR costs, and overhead costs are getting lower in line with the growing of its asset. The economic scale in Indonesian banking have not been fully achieved owing to the growing value of the assets in the last ten years, the average cost of HR and the relatively stable even slightly declining average cost.

The cost structure amongst bank groups proved that there is no correlation between the concentration and the level of bank competition. Competition among small banks is considerably more rigorous than the large and medium-sized ones although it does not make the cost structure of small banks supplementary. The difference in efficiency amongst small banks is much greater than that of the large and mediumsized ones. This phenomenon is due to segmented market in the Indonesian banking industry, thus the banks which are relatively less efficient still exist because they have enough loyal market segment. The difference in efficiency amongst banks is also a signal that the Indonesian banking competition is non price competition.

The level of competition of large and medium banks lead to oligopolistic competition, while small ones compete on a monopolistic condition. These findings reinforce the indication that while small banks have a cost structure that is less efficient comparing to large and medium-sized ones, the small banks can continue to exist because they have strong market power in its market segment respectively, even potentially close to monopoly on their respective market segments. Bank competition of oligopolistic large and mediumsized banks that better reflect on bank credit market, the deposit market and deposits of large banks are actually indications of monopolistic competition demonstrated by the difference or standard deviation of the interest rate is quite extensive amongst the large banks consistently in the period of 2000 until 2012. The standard deviation of the substantial cost of funds at a large bank group is suspected due to the standard deviation of the incredibly significant asset value in the group.

\section{REFERENCES}

Anginer, Deniz, Asli Demirgüç-Kunt, \& Min Zhu. 2014. "How Does Bank Competition Affect Systemic Stability?" Journal of Financial Intermediation, Vol 23, Issue 1, Pages 1-156 (January 2014).

US Department of Justice, Anti Trust Division, July 29 (2015). Herfindahl-Hirschman Index, http://www.justice.gov/atr/herfindahlhirschman-index

Bank Negara Malaysia, Base Rate (2015). http://www. bnm.gov.my/documents/2015/base_rates

Bank of Thailand, Commercial Bank Interest rate, www.bot.or.th/english/statistics/_layouts/ application/interest_rate

Bank Sentral of Philippines, Bank Interest rate, http:// www.bsp.gov.ph/statistics/keystat/intrates. htm

Barbosa, Kleino, Bruno de Paula Rocha, \& Fernando Salazar, (2015). "Assessing competition in the banking industry: A multi-product Approach", Journal of Banking and Finance, $50,340-362$

Beccalli, E., M. Anolli, \& G. Borello (2015), "Are European banks too big? evidence on economies of scale", Journal of Banking and Finance, 232-246

Berger, A N, Asli Demirgüç-Kunt, Ross Levine \& Joseph G. Haubrich, (2004), "Bank Concentration and Competition: An Evolution in the Making", Journal of Money, Credit and Banking

Berger, AN and TH Hannan, (1998). "The efficiency cost of market power in the banking industry: A test of the "quiet life" and related hypotheses", Review of Economics and Statistics

Bikker J \& Spierdijk (2008)." How Banking Competition Changed Over Time." De Nedherlandsche 


\section{JURNAL BISNIS \& MANAJEMEN}

ISSN 1412 - 3681

Bank Working Paper 167

Bikker, J. A. \& Haaf K (2000). "Competition, Concentration, and Their Relationship. An Empirical Analysis of The Banking Industry", Research Series Supervision No 30. De Nedherlandsche Bank, Amsterdam

Bikker, Jacob A, Sherrill Shaffer \& Laura Spierdijk, (2012). "Assessing Competition with the Panzar-Rosse Model: The Role of Scale, Costs, and Equilibrium," The Review of Economics and Statistics, MIT Press, vol. 94(4), pages 1025-1044, November.

Carbó, Santiago \& Humphrey, David \& Maudos, Joaquín \& Molyneux, Philip, (2009). "Crosscountry comparisons of competition and pricing power in European banking," Journal of International Money and Finance, vol. 28(1), pages 115-134, February.

Claessens, Stijn and Laeven, Luc, (2004). "What Drives Bank Competition? Some International Evidence." Journal of Money, Credit, and Banking 36 (3 Pt.2), 563-583

Davidson, Russell \& James G. MacKinno (1993). Estimation and Inference in Econometrics, Oxford: Oxford University Press

De Jonghe, Olivier \& Vennet, Rudi Vander, (2008). "Competition versus efficiency: What drives franchise values in European banking?," Journal of Banking \& Finance, vol. 32(9), pages 1820-1835, September.

Demsetz, H, (1973). "Industry structure, market rivalry, and public policy", Journal of Law and Economics

De Young, R., W.S. Frame, D.Glennon, \& P. Nigro (2011). "The Information Revolution and Small Business Lending: The Missing Evidence," Journal of Financial Services Research 39, 1933.

Dietrich, Andreas \& Gabriele Wazenreid, (2011). "Determinants of bank profitability before
Jurnal Bisnis \& Manajemen, 2016, Vol. XVII, No. 1, 58-72

and during the crisis: Evidence from Switzerland", Journal of International Financial Markets, Institutions and Money Volume 21 Pages 307-327

Feng, G. \& X. Zhang (2014). "Returns to scale at large banks in the US: A random coefficient stochastic frontier approach", Journal of Banking and Finance 39, 135-145.

Feng, G. \& A. Serlitis, (2010). "Efficiency, technical change and returns to scale in large U.S. Banks: Panel data evidence from an output distance function satisfying theoretical regularity". Journal of Banking and Finance, 34: 127-138.

Hughes, J. P. \& L. J. Mester (2013). "Who said large banks don't experience scale economies? evidence from a risk-rturn-driven cost function", Journal of Financial Intermediation 22, 559-585.

Kovner, A., J. Vickrey, \& L. Zhou (2014). “Do big banks have lower operating costs?", Federal Reserve Bank of New York Policy Review 20, 1- 27.

Maudos, Joaquín \& Solís, Liliana, (2011). "Deregulation, liberalization and consolidation of the Mexican banking system: Effects on competition," Journal of International Money and Finance, Elsevier, vol. 30(2), pages 337-353, March.

Otoritas Jasa Keuangan, Suku Bunga Dasar Credit (SBDK) Data Posisi Akhir Oktober (2013). http://www.ojk.go.id/sukubunga-dasarCredit

Panzar J.C., \& Rosse J.N., (1987). "Testing for monopoly equilibrium", Journal of Industrial Economics 25, 443-456

Ruby P. Kishan, Timothy P. Opiela, (2000). Bank Size, Bank Capital, and the Bank Lending Channel, Journal of Money, Credit and Banking, Vol. 32, No. 1, pp. 121-141 
Samad, Abdus, (2008). "Market structure, conduct and performance: Evidence from the Bangladesh banking industry", Journal of Asian Economics, Volume 19, Issue 2, April 2008, Pages 181-193

Shaffer, S, (2004). "Patern of Competition in Banking" Journal of Economics and Business 56, 287313

Restrepo-Tobon, D. \& S. C. Kumbhakar (2014). "Enjoying the quiet life under deregulation? not quite", Journal of Applied Econometrics 29, 333-343.
Wheelock D. C., \& P. W. Wilson (2012). "Do large Banks Have Lower Costs? New Estimates of Returns to Scale for U.S. Banks," Journal of Money, Credit and Banking. 44, 171-199.

Wheelock, D. C. \& P. W. Wilson (2009). "Robust nonparametric quantile estimation of efficiency and productivity change in U. S. commercial banking", Journal of Business and Economic Statistics 27, 354 - 368.

Wibowo, Buddi, (2015). "Analisis Empirik Kausalitas Konsentrasi dan Kompetisi Sektor Perbankan Serta Efeknya Terhadap Efisiensi dan Profitabilitas Bank", SSRN Working Papers Series. 